\title{
Pollutants of the Guaribas river water and their toxicogenic effects
}

\author{
João M. C. e Sousa • Vitor A. de Oliveira • Ana P. Peron • Ataíde M. V. Lima • \\ Ila B. S. Sales • Felipe C. C. da Silva • Leonardo H. G. M. Lima • Leomá A. Matos • \\ Marcus V. O. B. de Alencar - Luzia C. Rodrigues • Manik C. Shill • Muhammad T. Islam • \\ Ana Amélia C. Melo-Cavalcante • Cláudia C. Bonecker • Horácio F. J. Junior
}

Received: 14 September 2018/ Accepted: 8 March 2019/Published online: 18 March 2019

(C) The Author(s) 2019

\begin{abstract}
Tropical rivers used for water supply, irrigation and tourism have effects on anthropic activities. This study aimed to evaluate the presence of different pollutants in the aquatic environment of the Guaribas river water and their possible cytogenotoxic effects. For this, the presence of heavy metals and cyanobacteria along with the possible cytogenotoxic effects in the aquatic environment were evaluated at the city of Picos$\mathrm{PI}$ /Brazil, of its upstream, within and downstream regions. The results suggest that the electrical conductivity, total dissolved oxygen and solids, turbidity, color, chlorine and total phosphorus were above the allowed levels by the country's legislation, especially at the points associated with the main city. Water collected from the within and downstream regions showed a significant cytotoxic and mutagenic effects, regardless of seasons, where a positive correlation was observed between the genetic damage and heavy metal contents. Furthermore, mutagenic cyanotoxins were also found in the samples. These results pointed out that the Guaribas river contains physical and chemical contaminants, and cyanotoxins, that can cause genetic damages, suggesting a bad impact on the aquatic ecosystem, human and other animals directly or indirectly dependent on it. In
\end{abstract}

J. M. C. e Sousa · V. A. de Oliveira · A. P. Peron · A. M. V. Lima · I. B. S. Sales · F. C. C. da Silva · L. H. G. M. Lima Departamento de Ciências Biológicas, Universidade Federal do Piauí, Campus Senador Helvídio Nunes de Barros. Av. Cícero Duarte, Picos, Piauí CEP 64.600-000, Brazil

J. M. C. e Sousa · F. C. C. da Silva · M. V. O. B. de Alencar · A. A. C. Melo-Cavalcante

Programa de Pós-Graduação em Ciências Farmacêuticas, Universidade Federal do Piauí, Campus Ministro Petrônio Portela. Bairro Ininga. Teresina, Piauí CEP 64049-550, Brazil

L. A. Matos

Departamento de Ciências Biológicas, Universidade Federal do Piauí, Campus Ministro Petrônio Portela. Bairro Ininga, Teresina, Piauí CEP 64049-550, Brazil

L. C. Rodrigues · C. C. Bonecker · H. F. J. Junior

Departamento de Ciências Biológicas, Núcleo de Pesquisas em Limnologia, Ictiologia e Aquicultura, Universidade Estadual de Maringá, Av. Colombo 5790, Maringá, Paraná CEP 87020-900, Brazil

M. C. Shill

Department of Pharmaceutical Sciences, North South University, Dhaka, Bangladesh

M. T. Islam ( $₫)$

Department for Management of Science and Technology Development, Ton Duc Thang University,

Ho Chi Minh City 700000, Vietnam

e-mail: muhammad.torequl.islam@tdtu.edu.vn

M. T. Islam

Faculty of Pharmacy, Ton Duc Thang University, Ho Chi Minh City 700000, Vietnam 
conclusion, adequate attention is required to establish toxicogenic biomonitoring programs for the other tropical rivers in Brazil.

Keywords Aquatoxicology $\cdot$ Genotoxicity $\cdot$ Heavy metals $\cdot$ Cyanotoxins

\section{Introduction}

Aquatic environments that often serve as temporary or final receptors of a wide variety of contaminants may consequently contaminate the entire watershed (Tsangaris et al. 2011; Klobucar et al. 2012). Many of these toxic compounds released into the water are cytotogenotoxic in nature, therefore, may affect living organisms in the ecosystem through DNA damage (Akinboro et al. 2011). The presence of contaminating agents in our environment is responsible for many diseases in human, including cancer (Grzesiuk et al. 2018). Thus, it is extremely important to assess toxicological effects of the aquatic system in the viewpoint of environmental monitoring and risk assessment (Ansari et al. 2011; Kern et al. 2015).

Using fish, through the micronucleus (MN) test, is a popular genetic model to monitor pollutants and toxic contaminants in an aquatic environment (Hoshina et al. 2008). According to Cavas and Ergene-Gozukara (2005a, b), the species Oreochromis niloticus (tilapia) is an excellent test system for this purpose. This species is commonly found in estuaries around the world, and is recognized for its fast response to environmental changes (Jha 2004).

Heavy metals and cyanobacteria are the most common contaminants in an aquatic environment. Heavy metals are potentially genotoxic and carcinogenic, that bioaccumulate in the environment and can cause various degenerative diseases (Beyersmann and Hartwig 2008). Cyanobacteria, on the other hand, are capable of reproducing and releasing cyanotoxins that can exert mutagenic and carcinogenic effects on the ecosystem. An increased cyanobacteria biomass are directly associated with the eutrophication, a condition that usually causes intoxication of the aquatic biota and the population nearby (Lürling et al. 2017).

The Guaribas river is located in the Northeastern region of Brazil, in the semi-arid region and in the western part of the Piauí state. It is the main river of its watershed, and is considered a temporary river because it has a surface flow only during the rainy season. To be mentioned that this river is the main water reservoir for the 31 cities in Brazil, including the city Picos (Veloso et al. 2014). These regions are characterized by low and irregular rainfall areas in the country (Andrade-Júnior et al. 2006).

In recent years, the Guaribas river is suffering from intense anthropogenic activities, more significantly around the city Picos, which is the main city on its margins. In this urban area, the Guaribas river is affected by several problems such as the discharge of residential/hospital untreated sewage, disposal of domestic wastage, removal of ciliary forest and disordered population growth. These problems are responsible for silting, flooding, diseases, faster water evaporation and overheating of densely populated areas (Planap 2014). These anthropogenic activities are often detrimental to the ecosystem, and may persist in the environment, affecting not only the fauna and flora associated, but also the humans (Manzano et al. 2015).

Unfortunately, very little attention has been still provided regarding the presence of genotoxic and mutagenic agents and their impacts in the Brazilian semi-arid region, including the Picos, which is a growing socioeconomic city in Brazil. This study aimed to evaluate the presence of different pollutants in the aquatic environment of the Guaribas river water and their possible cytogenotoxic effects.

\section{Materials and methods}

Study area and sampling

Toxicogenic evaluation of water quality of Guaribas river was based on the sampling from upstream, within and downstream of different points in the city Picos, as characterized by the following: negative control (NC): water samples from the Bocaina reservoir, located $32 \mathrm{~km}$ upstream of the city Picos $\left(06^{\circ} 56^{\prime} 33^{\prime \prime} \mathrm{S}\right.$ and $\left.41^{\circ} 19^{\prime} 21^{\prime \prime} \mathrm{W}\right)$; P1 (point 1): before the city of Picos (city of Sussuapara) $\left(07^{\circ} 03^{\prime} 864^{\prime \prime} \mathrm{S}\right.$ and $\left.41^{\circ} 25^{\prime} 788^{\prime \prime} \mathrm{W}\right)$; P2 (point 2): $\left(07^{\circ} 04^{\prime} 964^{\prime \prime} \mathrm{S}\right.$ and $\left.41^{\circ} 27^{\prime} 879^{\prime \prime} \mathrm{W}\right)$; P3 (point 3): $\left(07^{\circ} 05^{\prime} 3135^{\prime \prime} \mathrm{S}\right.$ and $041^{\circ} 28^{\prime} 007^{\prime \prime} \mathrm{W}$ ); P4 (point 4): 
$\left(07^{\circ} 05^{\prime} 487^{\prime \prime} \mathrm{S}\right.$ and $\left.41^{\circ} 28^{\prime} 678^{\prime \prime} \mathrm{W}\right)$, located within the city; and P5 (point 5): $\left(07^{\circ} 06^{\prime} 047^{\prime \prime} \mathrm{S}\right.$ and $\left.41^{\circ} 29^{\prime} 145^{\prime \prime} \mathrm{W}\right)$, downstream (city of Aroeira) (Fig. 1). The points within the city were defined so that they were equally distant and close to places with water coming from small streams, receiving effluents from domestic sewage, hospital waste, gas stations, and so on.

The water samples were collected in February and September 2014, during rainy and dry seasons of the Northeast region of Brazil, respectively. The water sampling was done from the sub-surface $(25 \mathrm{~cm})$, and collected in $1.5 \mathrm{~L}$ polyethylene bottles and $150 \mathrm{~L}$ gallons, which were previously decontaminated by several washes with distilled water and $10 \%$ hydrochloric acid. Each sample was stored on ice and immediately taken to the laboratory for storage at $4{ }^{\circ} \mathrm{C}$, and subsequently used for physical and chemical analysis and the presence of cyanobacteria.

Physical and chemical analysis

During water sampling, physical and chemical parameters including electrical conductivity $(\mu \mathrm{S} / \mathrm{cm})$, total dissolved solids (TDS), $\mathrm{pH}$, dissolved oxygen (DO, ppm), and temperature $\left({ }^{\circ} \mathrm{C}\right)$ were analyzed using portable devices (HANNA). Other variables determined in the laboratory were: turbidity (NTU), color (UHz), nitrate $(\mathrm{mg} / \mathrm{L})$, nitrite $(\mathrm{mg} / \mathrm{L})$, sulfate $(\mathrm{mg} / \mathrm{L})$ and chlorine $(\mathrm{mg} / \mathrm{L})$ using a spectrophotometer (model DR 2500 , ODYSSEY - HACH), while total phosphorus $(\mathrm{mg} / \mathrm{L})$ was measured by the persulfate digestion method (Mackereth et al. 1978).

The levels of iron, nickel, cadmium, zinc, copper and chromium were determined by atomic absorption flame spectrophotometry according to APHA et al. (2005). After collection, the water samples were acidified immediately and subsequently subjected to acid digestion and concentration for reading in an atomic absorption spectrophotometer (Varian-AA50B model). Aluminum was quantified according to the method described by Rice et al. (2012).

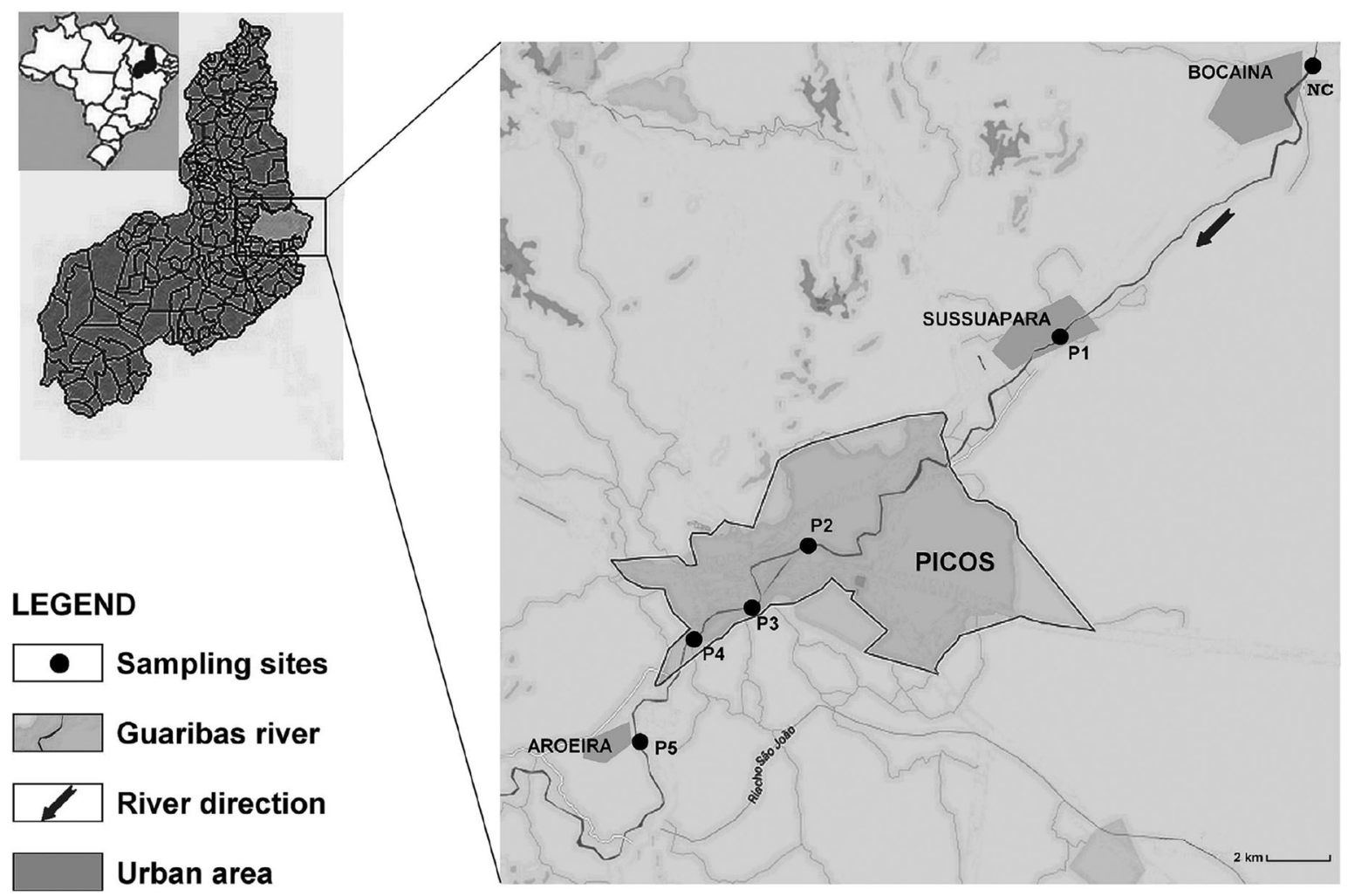

Fig. 1 Geographic location of the studied region and sampling points (Point 1 -upstream the city; Point 2 to Point 4-within the city; Point 5-downstream the city) of the Guaribas river 
Cyanobacteria analysis

Two water samples $(250 \mathrm{~mL})$, for each point and collection period, were collected for the identification and quantification of cyanobacteria. These analyses were performed at the Laboratory of Phytoplankton, at the Nucleus of Limnology, Ichthyology and Aquaculture (Nupélia), State University of Maringá (UEM), using the light microscopy technique (Nikon Eclipse 200 microscope), following the methodology described by the American Public Health Association (APHA et al. 2005) according to Marcon et al. (2010).

Cell viability with trypan blue, micronucleus (MN) and nuclear abnormalities (NA) test

The $O$. niloticus (same age, uniform in body weight and length), obtained from a local fish farm, was used in this study. The fishes were acclimated $\left(29 \pm 2{ }^{\circ} \mathrm{C}, \mathrm{pH} 7.8 \pm 0.3\right)$ and then transferred to aquaria containing water samples from the different collecting points under the previously mentioned conditions. Each aquarium with a capacity of $40 \mathrm{~L}$ received a specimen that remained exposed to the river water during 03,06 and 09 days (exposure times). Three animals were used per point and per control group, totaling 21 specimens. After the different exposure periods, $1.0 \mathrm{~mL}$ of blood was collected from each animal by gill puncture using heparinized syringes.

Blood $(0.5 \mathrm{~mL})$ of each fish was diluted in $1 \mathrm{~mL}$ of phosphate-buffered saline (PBS g/L, $\mathrm{pH} 7.4)$ and then centrifuged for $5 \mathrm{~min}$ at $3000 \mathrm{rpm}$. The supernatant was removed and a volume of PBS equivalent to the blood volume was added and gently mixed for cell suspension. An equivalent volume of $4 \%$ trypan blue dye was added to the cells. After $2 \mathrm{~min}$, aliquots of $5 \mu \mathrm{L}$ of the suspension of each fish were placed in Newbauer's chamber and after cell decantation, 500 cells were counted, which were classified as stained (ruptured) and not stained (intact). The results were presented as percentage of cell viability.

The bioassay for the MN test was conducted according to Da Silva and Fontanetti (2006). Briefly, the slides were prepared with fish blood smears and fixed in methanol for $10 \mathrm{~min}$ and finally stained with $10 \%$ Giemsa. Cells (3000) were analyzed for each subject using optical microscopy at $1000 \times$ magnification. The MN and nuclear morphological changes found in fish erythrocytes were characterized according to Carrasco et al. (1990). The positive control used for the MN test in fish was cyclophosphamide (CPA) at a concentration of $4 \mathrm{mg} / \mathrm{L}$ injected intraperitoneally (i.p.), below the pectoral fin (Bolognesi and Hayashi 2011). The study was approved by the Ethics Committee of the Federal University of Piauí (UFPI) (Approval No. 108/14).

Statistical analysis

Analysis of variance (ANOVA) was used to detect statistical differences between the periods and collection sites, with Tukey's post-test for the physical and chemical parameter analysis, and Nested RM-MANOVA for toxicogenic analyses. The Pearson's correlation was used to evaluate the relationship between the genotoxic damage and accumulated metals, while simple regression analysis was done for detecting the presence of metal contaminants on the effect of genetic and cellular damages. All data were analyzed with STATISTICA 7.0 software, considering $p<0.05$ at $95 \%$ confidence of intervals.

\section{Results}

Analysis of physical and chemical parameters

The water quality of the collection points was compared with the indexes proposed by the National Environment Council (CONAMA-357/2005). The results suggest that the observed values (e.g., TDS, DO, turbidity, color, chlorine, and total phosphorus) were above the acceptable limit during the study periods. It was also observed that the turbidity, color, nitrate, sulfate, chlorine and PT in points inside (P2, P3 and P4) and downstream of the city (P5) presented values significantly higher $(p<0.05)$ when compared to the NC and upstream of the city (P1) (Table 1).

The sample water was also found to contain a higher level of $\mathrm{Fe}, \mathrm{Zn}, \mathrm{Cu}, \mathrm{Cr}$ and $\mathrm{Al}$ than the values allowed by the Brazilian Environmental Legislation (CONAMA-357/2005) at the P2, P4 and P5 points. Among the 
Table 1 Physical and chemical variables and indicators of water quality in the Guaribas river during summer and rainy seasons

\begin{tabular}{|c|c|c|c|c|c|c|c|c|c|c|c|c|c|}
\hline \multirow[t]{2}{*}{ Variables } & \multirow[t]{2}{*}{ MVA } & \multicolumn{6}{|c|}{ Rainy season/2014 } & \multicolumn{6}{|c|}{ Dry season/2014 } \\
\hline & & $\mathrm{NC}$ & $\mathrm{P} 1$ & $\mathrm{P} 2$ & P3 & $\mathrm{P} 4$ & P5 & $\mathrm{NC}$ & $\mathrm{P} 1$ & $\mathrm{P} 2$ & P3 & P4 & P5 \\
\hline $\begin{array}{l}\text { Cond. } \mu \mathrm{S} / \\
\mathrm{cm}\end{array}$ & - & 85 & 82 & 337 & 374 & 472 & 405 & 89 & 127 & 990 & 960 & 970 & 980 \\
\hline TDS & $<500(\mathrm{ppm})$ & 143 & 126 & 174 & 185 & 236 & 229 & 186 & 193 & $508^{*}$ & 485 & 493 & 490 \\
\hline $\mathrm{pH}$ & 6 a 9 & 7.3 & 7.5 & 7.2 & 7.4 & 7.4 & 7.6 & 7.4 & 6.5 & 7.8 & 7.5 & 8.1 & 7.2 \\
\hline DO & $>5(\mathrm{ppm})$ & 6.9 & 5.1 & $2.2^{*}$ & $2.1^{*}$ & $2.5^{*}$ & $2.8^{*}$ & 6.1 & 3.7 & $4.2^{*}$ & $0.8^{*}$ & $2.0^{*}$ & $1.5^{*}$ \\
\hline Turbidity & $<5$ (NTU) & 3.7 & 4.5 & 4.8 & 4.7 & $30.7 *^{\mathrm{a}}$ & 3.9 & 3.9 & 4.4 & $47.6^{*^{\mathrm{a}}}$ & $51.4^{* \mathrm{a}}$ & $27.4^{*}$ & $50.7 *^{\mathrm{a}}$ \\
\hline Color & $<75(\mathrm{UHz})$ & 48 & 27.3 & $156^{* \mathrm{a}}$ & $86.6^{*^{\mathrm{a}}}$ & $100 *^{\mathrm{a}}$ & $378.3 *^{\mathrm{a}}$ & 67 & 72 & $476^{* \mathrm{a}}$ & $392 *^{\mathrm{a}}$ & $472 *^{\mathrm{a}}$ & $486^{*^{\mathrm{a}}}$ \\
\hline Nitrate & $<10(\mathrm{mg} / \mathrm{L})$ & 0.9 & 0.03 & 0.4 & 0.2 & 0.4 & $6.5^{\mathrm{a}}$ & 1.3 & 1.5 & $4.3^{\mathrm{a}}$ & $8.0^{\mathrm{a}}$ & 2.5 & $6.0^{\mathrm{a}}$ \\
\hline Nitrite & $<1(\mathrm{mg} / \mathrm{L})$ & 0.01 & $\mathrm{Nd}$ & $\mathrm{Nd}$ & 0.01 & 0.01 & 0.04 & 0.01 & 0.01 & 0.02 & 0.1 & 0.05 & 0.1 \\
\hline Sulfate & $\begin{array}{l}<250(\mathrm{mg} / \\
\mathrm{L})\end{array}$ & 15.67 & $\mathrm{Nd}$ & $0.01 \mathrm{~b}$ & $1.8 \mathrm{~b}$ & $1.1 \mathrm{~b}$ & $2.1 \mathrm{~b}$ & 13.6 & 3.9 & 27 & $43.6^{\mathrm{a}}$ & $39.3^{\mathrm{a}}$ & $43^{\mathrm{a}}$ \\
\hline Chlorine & $\begin{array}{l}<0.01(\mathrm{mg} / \\
\mathrm{L})\end{array}$ & $0.19 *$ & $0.05^{*}$ & $0.17 *$ & $0.09 *$ & $0.06^{*}$ & $0.5^{*^{\mathrm{a}}}$ & $0.1 *$ & $0.1 *$ & $0.6^{* \mathrm{a}}$ & $0.7^{* \mathrm{a}}$ & $0.3^{*}$ & $0.6^{* \mathrm{a}}$ \\
\hline PT & $\begin{array}{l}<0.05(\mathrm{mg} / \\
\mathrm{L})\end{array}$ & 0.02 & $0.09 *$ & $2.6^{*^{\mathrm{a}}}$ & $1.6^{*^{\mathrm{a}}}$ & $1.4^{* \mathrm{a}}$ & $2.9^{*^{\mathrm{a}}}$ & 0.03 & $0.07 *$ & $2.4^{*^{\mathrm{a}}}$ & $1.6^{* \mathrm{a}}$ & $1.4^{*^{\mathrm{a}}}$ & $2.9^{* \mathrm{a}}$ \\
\hline
\end{tabular}

MVA maximum value allowed by Brazilian Law, $N d$ not detected

*Values above the limits permitted by Brazilian laws-CONAMA 357/05

${ }^{a}$ Values above when compared with $\mathrm{NC}$ (control) and P1 referring to the same parameter and period $(p<0.05)$

${ }^{\mathrm{b}}$ Lower values when compared to $\mathrm{NC}$ and $\mathrm{P} 1$, referring to the same parameter and period $(p<0.05)$

analyzed metals, only $\mathrm{Fe}$ showed a significant difference between the periods. Comparing the collection points, it was found that the P3, P4 and P5 were the points that differed more in relation to the NC and P1 (Table 2).

Identification of cyanobacteria in water samples

Density of cyanobacteria was not above the values allowed by the Brazilian Legislation in any of the points or periods analyzed. However, the presence of Oscillatoria sp., Aphanizomenon sp. and Synechocystis aquatilis, which produce microcystins (MCs), and Cylindrospermopsis raciborskii and Aphanizomenon sp. that produces Cylindrospermopsina (CYN) was observed. All cyanobacteria were found at the P2-P5 points in the city, at least in one period. Moreover, the species Planktothrix agardhii, that produces Anatoxin- $\alpha$ (Antx- $\alpha$ ) was also present at $\mathrm{P} 2$ point during the dry season (Table 3).

Evaluation of cell viability, MN, and NA frequency in $O$. niloticus

The evaluation of the cellular viability during rainy season showed that the points within the city (P2, P3 and $\mathrm{P} 4)$, influenced by anthropogenic activities, showed the lowest erythrocyte viability $(p<0.05)$ when compared to the NC and P1, at least at one exposure time (ET). For the dry season, the points P3, P4 and P5 showed the lowest erythrocyte viability $(p<0.05)$ when compared to the NC. Point P1 (upstream the city) did not show cytotoxic effect when compared to the NC in the two seasons analyzed (Fig. 2).

The frequency of MN and NA were evaluated to detect the pollutants released by the anthropogenic activity in the river water, which further was helpful to detect the chromosomal mutations, cell death and nuclear alterations in $O$. niloticus erythrocytes. The rainy season did not differ statistically from the dry season, in relation to the total cell damages. The comparison of the ET between the seasons showed a statistical difference only for the first time analyzed (3 days). In the rainy season, P3, P4 and P5 were cytotoxic and mutagenic in at least one (9 days) ET analyzed. Again, during the dry season, all points within the city, P2-P5 also showed cytotoxicity and mutagenicity in surface waters (Table 4). 


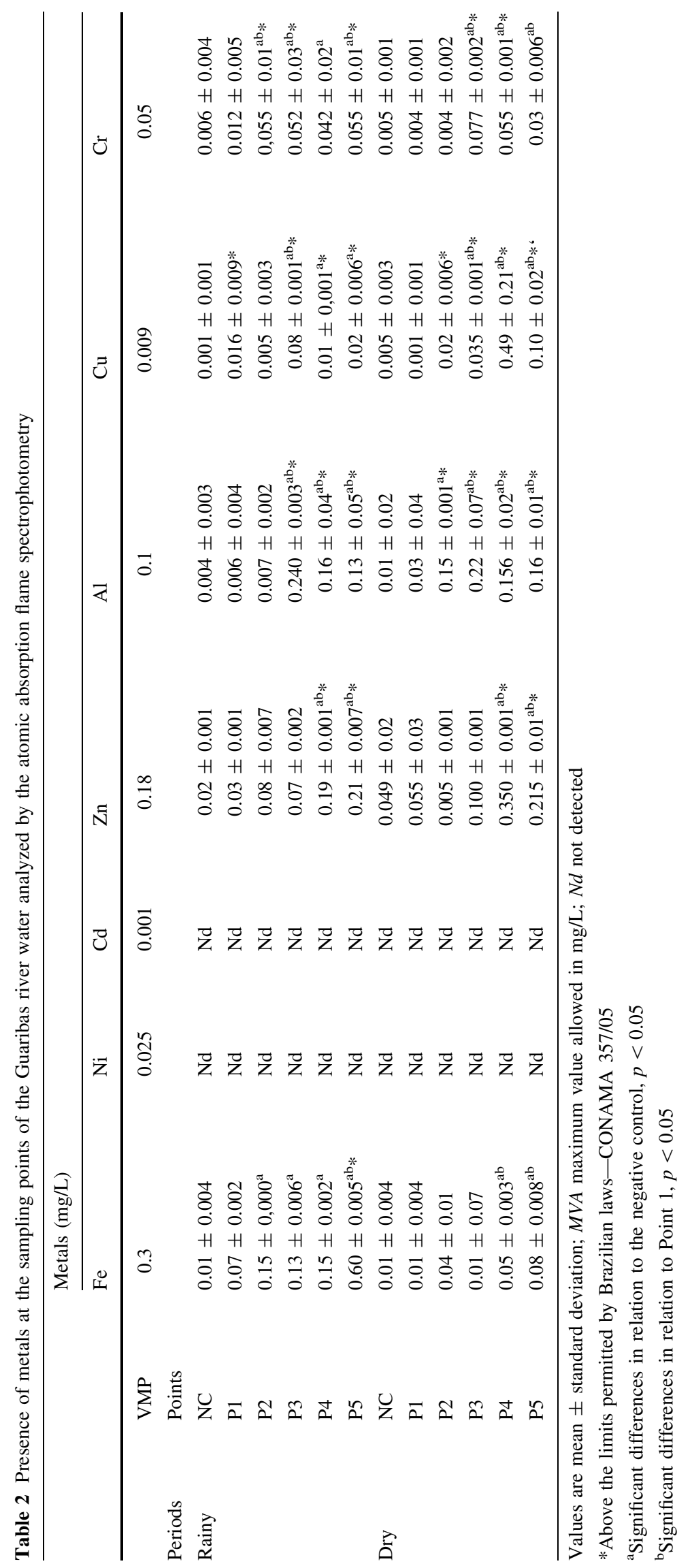


Table 3 Identification and density of cyanobacteria (cells $/ \mathrm{mL})$ in water samples of the Guaribas river during the study periods

\begin{tabular}{|c|c|c|c|c|}
\hline Points & Rainy season & & Dry season & \\
\hline \multirow[t]{6}{*}{$\mathrm{CN}$} & Aphanizomenon sp. & 1 & Aphanocapsa delicatissima & 16 \\
\hline & Cyanodyction imperfectum & 32,398 & C. imperfectum & 3615 \\
\hline & Cyanodyction sp. & 818 & M. tenuissima & 3632 \\
\hline & Planktolyngbya limnetica & 17,999 & & \\
\hline & Pseudanabaena sp. & 245 & & \\
\hline & Romeria gracilis & 491 & & \\
\hline \multirow[t]{4}{*}{ P1 } & Cyanodyction sp. & 965 & Cyanodyction sp. & 196 \\
\hline & Merismopedia tenuissima & 930 & M. tenuissima & 98 \\
\hline & Romeria elegans & 144 & R. elegans & 785 \\
\hline & & & R. gracilis & 65 \\
\hline \multirow[t]{5}{*}{$\mathrm{P} 2$} & Aphanizomenon sp. & 1136 & C. raciborskii & 890 \\
\hline & Cylindrospermopsis raciborskii & 480 & Phormidium sp. & 1789 \\
\hline & Phormidium sp. & 6546 & S. aquatilis & 256 \\
\hline & Planktothrix agardhii & 988 & Oscillatoriaceae & 3589 \\
\hline & Oscillatoriaceae & 500 & & \\
\hline \multirow[t]{2}{*}{ P3 } & C. raciborskii & 256 & Aphanizomenon sp. & 670 \\
\hline & Oscillatoria sp. & 820 & Oscillatoria sp. & 768 \\
\hline \multirow[t]{3}{*}{2.1} & Phormidium formosum & 1489 & Phormidium sp. & 456 \\
\hline & Synechocystis aquatilis & 2869 & Pseudanabaena limnetica & 32 \\
\hline & & & Oscillatoriaceae & 811 \\
\hline \multirow[t]{7}{*}{ P4 } & C. raciborskii & 784 & C. raciborskii & 2387 \\
\hline & C. imperfectum & 65 & C. imperfectum & 33 \\
\hline & M. glauca & 16 & M. glauca & 1 \\
\hline & M. tenuissima & 16 & M. tenuissima & 49 \\
\hline & Oscillatoria sp. & 3941 & Oscillatoria sp. & 930 \\
\hline & Phormidium sp. & 323 & P. formosum & 1239 \\
\hline & Synechocystis aquatilis & 834 & & \\
\hline \multirow[t]{5}{*}{ P5 } & Aphanizomenon sp. & 1728 & C. raciborskii & 3615 \\
\hline & C. raciborskii & 336 & P. formosum & 230 \\
\hline & P. formosum & 102 & Phormidium sp. & 167 \\
\hline & S. aquatilis & 895 & Oscillatoriaceae & 496 \\
\hline & Total & 78,131 & & 26,815 \\
\hline
\end{tabular}

50,000 cell/mL: maximum limits permitted by the Brazilian Legislation

The presence of MN and the types of NA found were nuclear shoots, erythrocytes exhibiting cell death (vacuolated nucleus, cell fragmentation, karyolysis and vacuolated cytoplasm), as well as erythrocytes with NA, including notched, lobed and blebbed according to Carrasco et al. (1990) (Fig. 3 and Table 5).

Statistical correlations between the toxicogenic parameters and metal presence

The genetic damage in the $O$. niloticus was statistically correlated with the observed results of heavy metals. The metals $\mathrm{Zn}(r=0.536)$ and $\mathrm{Al}(r=0.769)$, and $\mathrm{Cu}(r=0.691)$ and $\mathrm{Al}(r=0.751)$ were more correlated with the formation of MN and apoptotic cell death in the rainy and dry periods, respectively. Among the metals analyzed, $\mathrm{Al}$ was the one that best presented the simple regression model for the two evaluated periods: genetic damage $=84.03+426.78 \times \mathrm{Al}$ (rainy) and genetic damage $=119.67+346.39 \times \mathrm{Al}$ (dry) . 


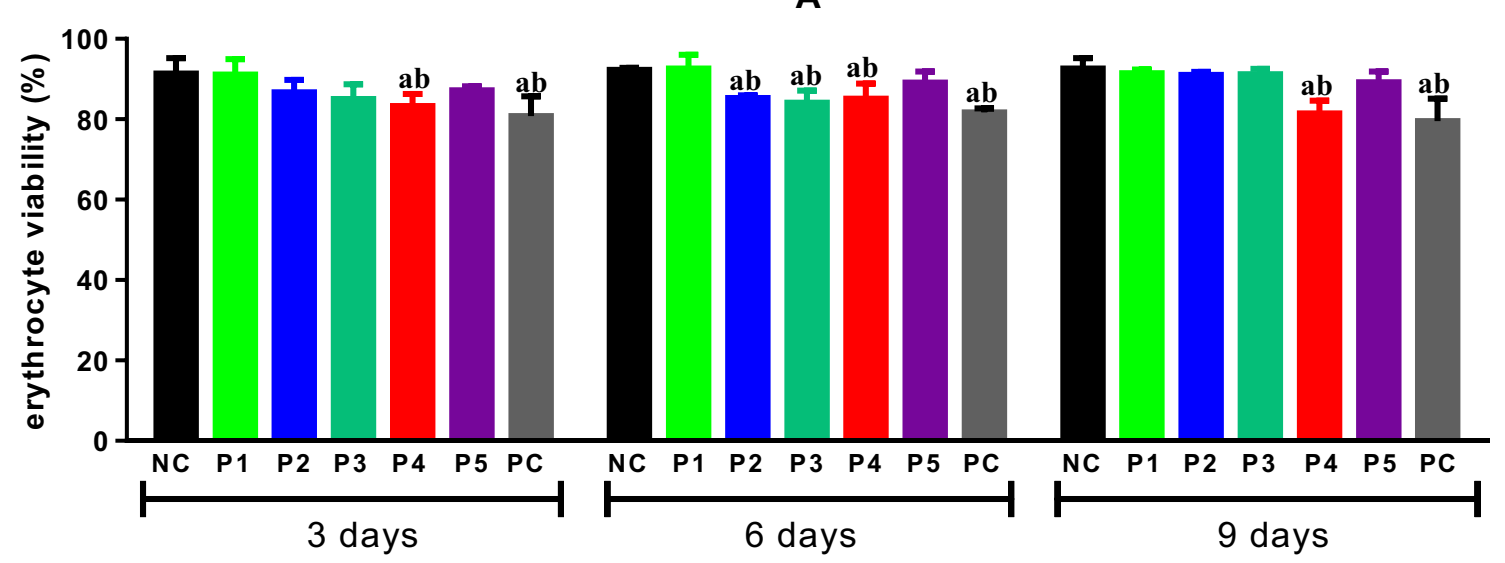

B

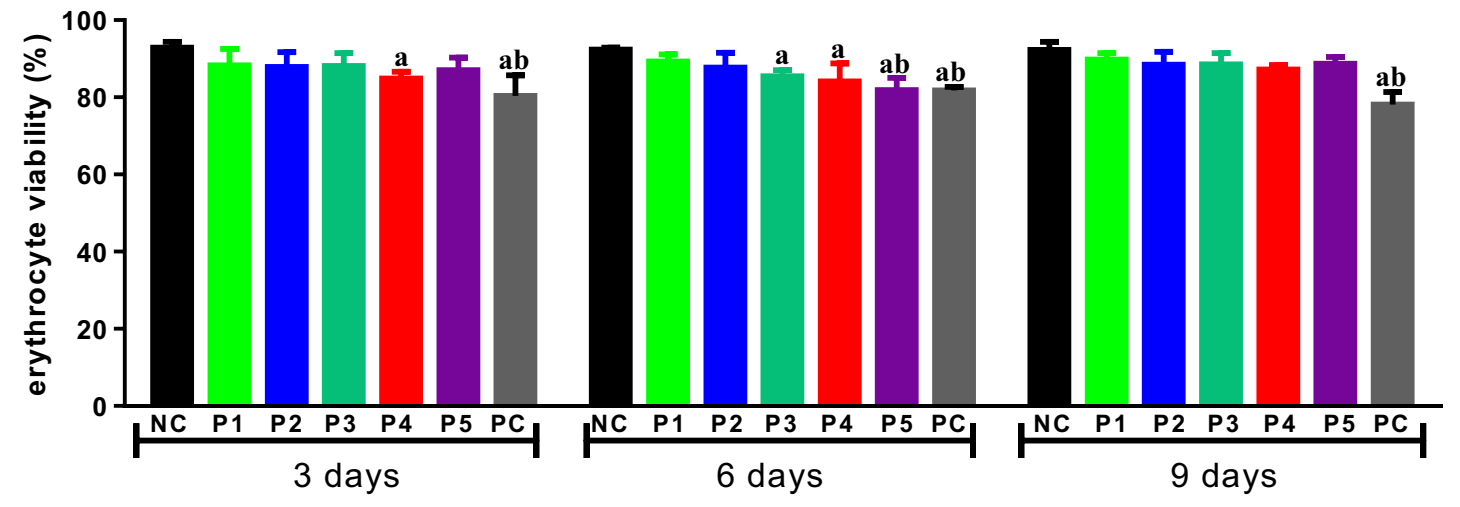

Fig. 2 O. niloticus erythrocytes viability exposed to the water samples at five sampling points of the Guaribas River (Picos-PI/ Brazil) and negative (NC) and positive (PC) controls. [a rainy and b dry season; $N C$ negative control, $P C$ distilled water with cyclophosphamide at $4 \mathrm{mg} / \mathrm{L}, E T$ exposure time. Nested RM-MANOVA—followed by the Tukey's post-test; $p<0.05$ when compared to the ${ }^{\mathrm{a}} \mathrm{NC}$ and $\left.{ }^{\mathrm{b}} \mathrm{P} 1\right]$

Table 4 Total erythrocyte cell damage (chromosomal + nuclear) in O. niloticus exposed to the water samples of the Guaribas River

\begin{tabular}{|c|c|c|c|c|c|c|}
\hline \multirow[t]{2}{*}{ Points } & \multicolumn{3}{|c|}{$\begin{array}{l}\text { Rainy season/2014 } \\
(\text { mean } \pm \text { SD) } \\
\text { ET }\end{array}$} & \multicolumn{3}{|l|}{$\begin{array}{l}\text { Dry season/2014 } \\
(\text { mean } \pm \text { SD) } \\
\text { ET }\end{array}$} \\
\hline & 3 days & 6 days & 9 days & 3 days & 6 days & 9 days \\
\hline $\mathrm{NC}$ & $14.00 \pm 3.20$ & $30.40 \pm 3.50$ & $31.70 \pm 5.70$ & $34.00 \pm 3.70$ & $40.90 \pm 4.00$ & $53.10 \pm 4.10$ \\
\hline $\mathrm{P} 1$ & $13.00 \pm 3.40$ & $26.30 \pm 5.60$ & $41.10 \pm 4.70$ & $28.00 \pm 3.50$ & $38.70 \pm 6.00$ & $49.10 \pm 5.10$ \\
\hline $\mathrm{P} 2$ & $26.00 \pm 7.30$ & $36.80 \pm 6.90$ & $37.10 \pm 6.50$ & $43.80 \pm 7.00$ & $53.30 \pm 5.40^{\mathrm{ab}}$ & $65.20 \pm 9.00^{\mathrm{ab}}$ \\
\hline P3 & $29.30 \pm 5.40^{\mathrm{ab}}$ & $57.10 \pm 7.60^{\mathrm{ab}}$ & $70.80 \pm 7.20^{\mathrm{ab}}$ & $70.30 \pm 9.10^{\mathrm{ab}}$ & $58.40 \pm 6.20^{\mathrm{ab}}$ & $73.10 \pm 5.40^{\mathrm{ab}}$ \\
\hline P4 & $29.80 \pm 12.70^{\mathrm{ab}}$ & $59.40 \pm 6.20^{\mathrm{ab}}$ & $91.40 \pm 7.30^{\mathrm{ab}}$ & $53.10 \pm 5.90^{\mathrm{ab}}$ & $40.00 \pm 5.10$ & $54.80 \pm 2.90$ \\
\hline P5 & $20.80 \pm 6.40$ & $39.70 \pm 6.60$ & $62.10 \pm 4.70^{\mathrm{a}}$ & $50.70 \pm 6.00^{\mathrm{ab}}$ & $48.00 \pm 8.80$ & $57.40 \pm 6.00$ \\
\hline $\mathrm{PC}$ & $22.70 \pm 3.30$ & $83.30 \pm 8.00^{\mathrm{ab}}$ & $92.70 \pm 7.40^{\mathrm{ab}}$ & $45.20 \pm 6.40$ & $74.20 \pm 6.40^{\mathrm{ab}}$ & $102.60 \pm 6.40^{\mathrm{ab}}$ \\
\hline
\end{tabular}

$N C$ negative control, $P C$ distilled water with cyclophosphamide at $4 \mathrm{mg} / \mathrm{L}, E T$ exposure time, Nested RM-MANOVA-followed by the Tukey's post-test; $p<0.05$ when compared to the ${ }^{\mathrm{a}} \mathrm{NC}$ and ${ }^{\mathrm{b}} \mathrm{P} 1$ 


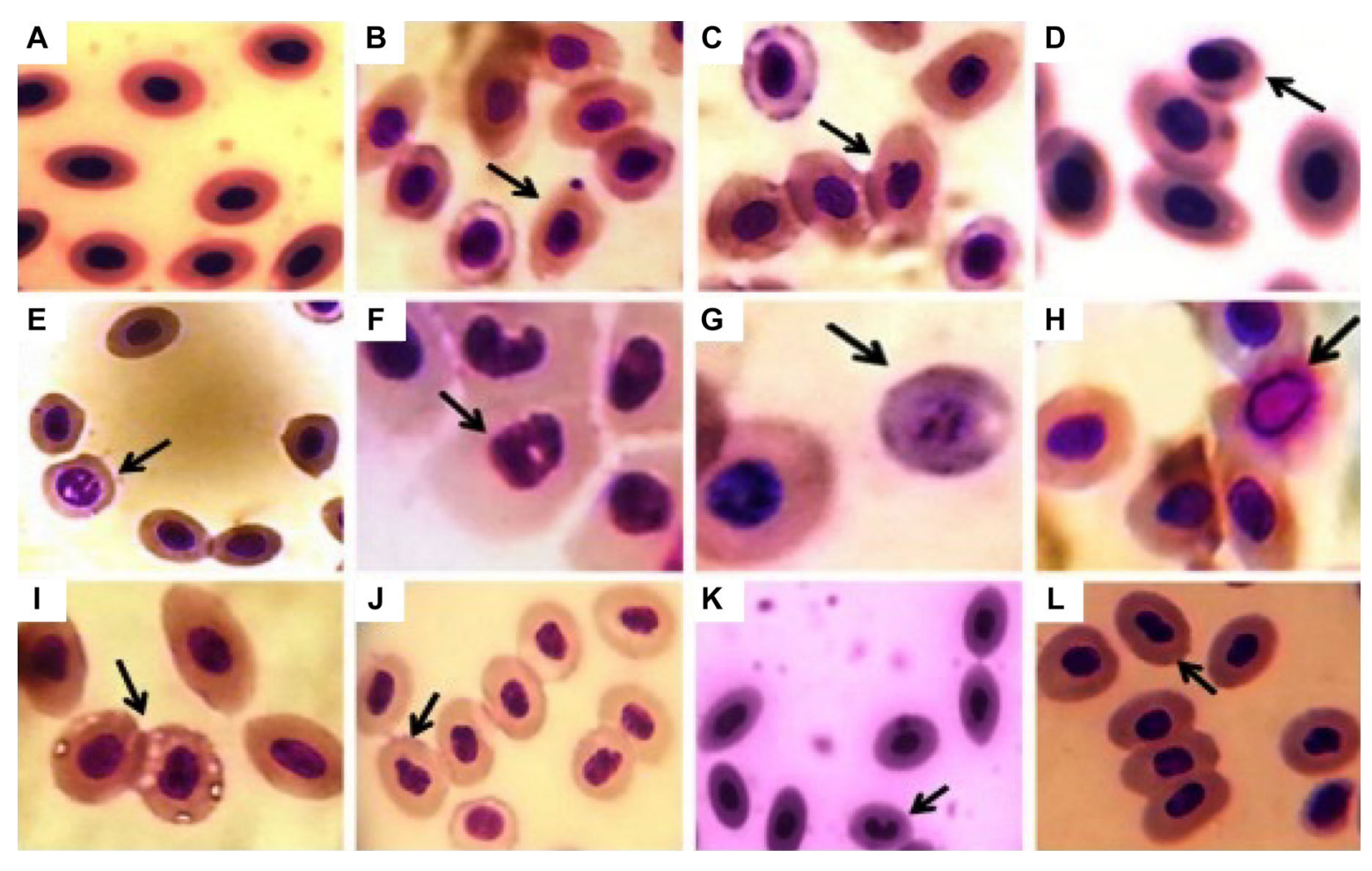

Fig. $3 \mathrm{MN}$, cell death and NA found in erythrocytes of $O$. niloticus exposed to the water at five points of the Guaribas River (Picos-PI/Brazil). [(a) normal cells; (b) micronucleus (MN); (c) nuclear shoot; (d) microcyst; (e) and (g) nuclear fragmentation; (f) vacuolated nucleus; (h) karyolysis; (i) vacuolated cytoplasm; (j) erythrocyte with "notched" core; (k) erythrocyte with lobed nucleus; and (l) erythrocyte with blebbed nucleus. $(\times 1000)]$

\section{Discussion}

Aquapollution is a one of the leading problems in the world. It is due to the increasing numbers of industrial, agricultural and domestic activities regarding the generation and discharge of the pollutants in our ecosystem. Water pollution leads to a number of deleterious effects on organisms living in its areas, as well as human health (Yu et al. 2013). Among the lethal and sub-lethal effects caused by these complex mixtures in water, fertility problems as well as cellular, metabolic, and DNA damages are noteworthy (Bianchi et al. 2011).

In our study, the genotoxic bioassay performed in erythrocytes of $O$. niloticus showed cytotoxicity and mutagenicity at the points, within and downstream the city Picos, with statistically significant values of MN, apoptosis and NA as compared to the NC and in P1 in at least one ET analyzed. Studies, such as those of Erbe et al. (2011), Duarte et al. (2012), Klobucar et al. (2012), Marcon et al. (2010) and Oliva et al. (2012), using the technique of $\mathrm{MN}$ and NA in fish, detected relationships between genetic damage found in animal erythrocytes in the presence of heavy metals in the aquatic environments.

The toxic effects of $\mathrm{Cu}$ are well known in various aquatic organisms (Zitoun et al. 2019), including fish (Leung et al. 2014). Fish cells are more sensitive to $\mathrm{Cu}$ than mammalian cells (Leung et al. 2014). On the other hand, Cr may damage DNA in a number of ways, including double-strand breaks (DSBs) that generate chromosomal aberrations, formation of MN and DNA adducts, sister chromatid exchange, and changes in DNA transcription and replication (Peng et al. 2015). In a study, Zhu et al. (2004) found a positive correlation between the erythrocytes of Cyprinus carpio exposed to concentrations of hexavalent $\mathrm{Cr}$, ranging from 0.001 to $0.1 \mathrm{mg} / \mathrm{L}$. According to Matsumoto et al. (2006), total $\mathrm{Cr}$ concentrations of $0.01 \mathrm{mg} / \mathrm{L}$ were able to promote an increase in micronucleated erythrocytes and NA levels in $O$. niloticus. In our study, both $\mathrm{Cu}$ and $\mathrm{Cr}$ values were above the acceptable ranged at P2-P5 points.

Exposure to $\mathrm{Al}$ leads to toxic effects in animal cells. Most studies on cytotoxic and genotoxic potential of $\mathrm{Al}$ were carried out in vitro and in cell cultures (Lima et al. 2007). It has been demonstrated that $\mathrm{Al}$ induces MN and chromosomal aberrations (Ternjej et al. 2010). Pereira et al. (2013) suggested that Al at high 


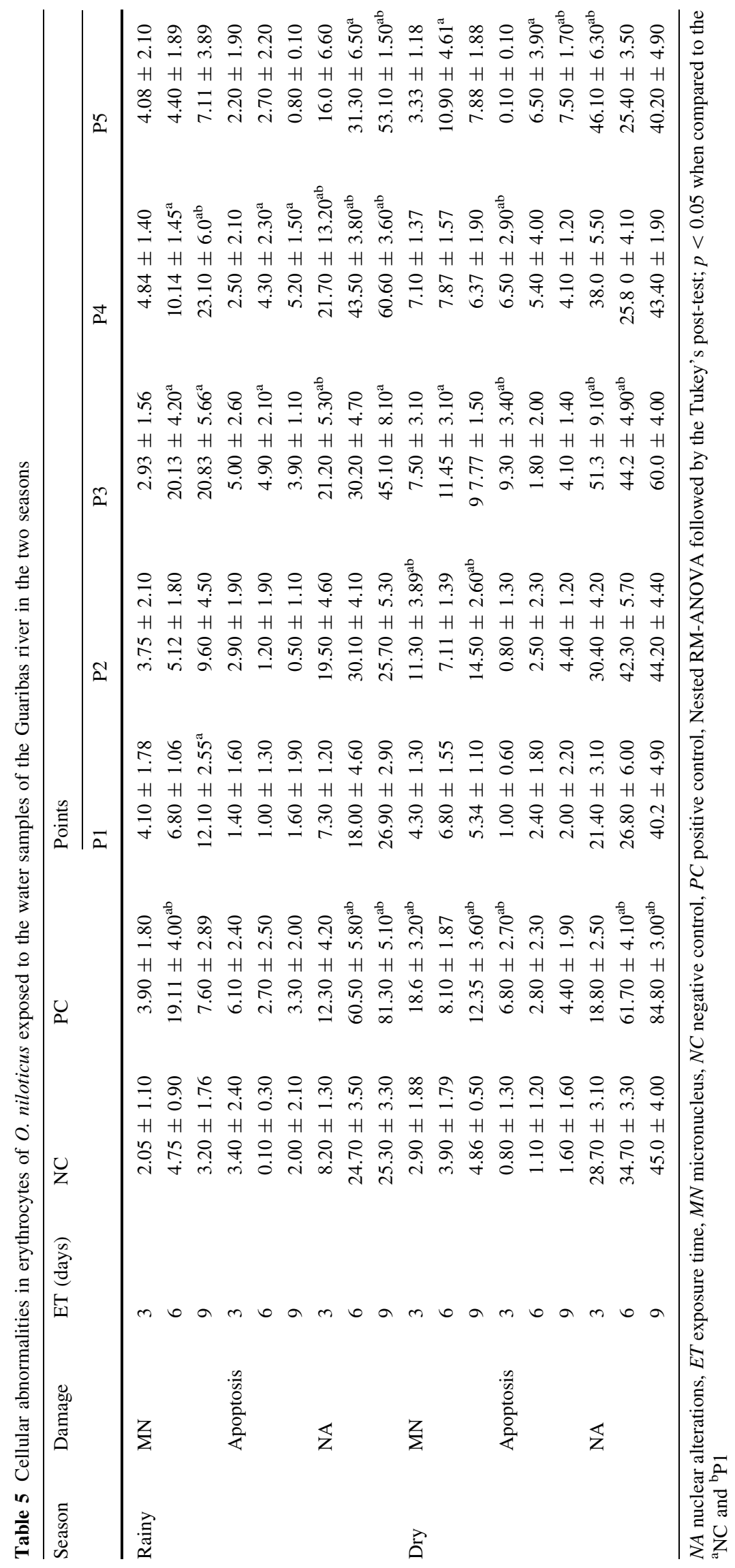


concentration induced toxicity in fish cell cultures and indicated the importance of genotoxicity assessment in living organisms in contaminated water.

The presence of these heavy metals inside the cell also provokes the production of reactive oxygen species (ROS) (Chakraborty et al. 2009), which are responsible for several types of DNA fragmentation and cell death (Gómez-Mendikute and Cajaraville 2003). In our study, statistically significant differences were found for the cell death (apoptosis) at points P3 and P4 (rainy season), and P3, P4 and P5 (dry season), with cells showing fragmented and vacuolated nuclei, karyolysis and vacuolated cytoplasm (Fig. 3e-i). Cells in apoptosis, found in the study may be not only related to the increased production of ROS, but also by the development of adaptive response caused by heavy metals in synergism with other potentially harmful chemicals (Fryzova et al. 2018).

In addition to genotoxicological studies, with heavy metals in an aquatic environment, another concern is the presence of cyanobacteria producing potentially mutagenic and carcinogenic toxins, called cyanotoxins (Humpage et al. 2000). In our study, we also found some cyanotoxin producing capable species in the sampled water, although the density of the bacteria was within the limits allowed by the Brazilian laws. The species Oscillatoria sp, Aphanizomenon sp., and Synechocystis aquatilis are potential producers of microcystins (MCs). MCs are one of the most studied groups of cyanotoxins in relation to their genotoxic activity (Zegura et al. 2011). Da Silva et al. (2011) observed DNA fragmentation and cell death in erythrocytes of $O$. niloticus in the presence of MN. On the other hand, Chen et al. (2011) evaluated genotoxic effects and found DNA fragmentation of plant cells exposed to MCs, while Sieroslawska (2013) noticed synergism in mutagenicity in the presence of cyanotoxins CYN and Antx using the Ames test.

The low density of some species may be related to the period of the year, since some species of cyanobacteria have their blooms at the beginning of the rainy season, and our study was developed in the middle of the both seasons. In addition, environmental conditions (nutrient concentrations, stratification, and temperature) will usually determine the intensity of these blooms (Chellappa and Costa 2003).

The presence of potentially toxic species in the river may lead to the release of genotoxic cyanotoxins, thus creating a genotoxicological environment, formed by the mixture of heavy metals, cyanotoxins and other contaminants released by the anthropogenic activities. The aromatic and polycyclic hydrocarbons (PHAs) and organochlorine compounds, although not studied in our present study, are normally released and are frequent in aquatic environments suffering from the human activities from industrial, agricultural and domestic effluents, may also be involved in the cytotoxic and mutagenic effects in the aquatic environment (Di Giorgio et al. 2011; Mai et al. 2013). Therefore, organisms exposed to this type of environment may fall in difficulty in cell division, suffer by genetic and/or chromosomal mutations at the cellular level, as well as reproductive failure and, consequently, their existence in the aquatic system (Farmer and Singh 2008; Leme and Marin-Morales 2009).

\section{Conclusion}

The Guaribas river water contains various contaminants, including heavy metals, non-metals and pathogenic bacteria. Water samples collected from different points exhibited significant cytotoxic and mutagenic effects in O. niloticus. Not only the upstream, but also the points within and downstream of the city were found to be polluted by the anthropogenic activity. Additional studies are needed regarding the determination of the presence of other mutagens released by these activities along with the other physical and chemical parameters in this river's aquatic environment.

Acknowledgements We are owed to the Center for Research in Limnology, Ichthyology and Aquaculture (NUPELIA) and the Federal University of Piauí (UFPI), Brazil, for the logistical supports. We are also thankful to the Central Public Health Laboratory of the State of Piauí (LACEN-PI) and CNPq/CAPES for providing laboratory facilities and fund, respectively.

\section{Compliance with ethical standards}

Conflict of interest None declared.

Open Access This article is distributed under the terms of the Creative Commons Attribution 4.0 International License (http:// creativecommons.org/licenses/by/4.0/), which permits unrestricted use, distribution, and reproduction in any medium, provided you give appropriate credit to the original author(s) and the source, provide a link to the Creative Commons license, and indicate if changes were made. 


\section{References}

Akinboro A, Mohammed K, Rathnasamy S, Muniandy VR (2011) Genotoxicity assessment of water samples from the Sungai Dua River in Pulau Pinang, Malaysia, using the Allium cepa test. Trop Life Sci Res 22:23-35. https://www.ncbi.nlm.nih.gov/pmc/ articles/PMC3819085/pdf/tlsr-22-2-023.pdf

Andrade-Júnior AS, Silva EFES, Bastos EA, Melo FB, Leal CM (2006) Use and quality of groundwater for irrigation in semi-arid region of the Piauí State, Brazil. Revista Brasileira de Engenharia Agrícola e Ambiental 10:873-880. https://doi.org/10.1590/ S1415-43662006000400014

Ansari RA, Rahman S, Kaur M, Anjum S, Raisuddin S (2011) In vivo cytogenetic and oxidative stress-inducing effects of cypermethrin in freshwater fish, Channa punctata Bloch. Ecotoxicol Environ Safety 74:115-150. https://doi.org/10.1016/j. ecoenv.2010.08.036

APHA, AWWA, WPCF (2005) Standard methods for the examination of water and wastewater. 21st ed. American Public Health Association, Washington, DC. https://books.google.com.bd/books/about/Standard_Methods_for_the_Examination_of. html?id=buTn1rmfSI4C\&redir_esc $=y$

Beyersmann D, Hartwig A (2008) Carcinogenic metal compounds: recent insight into molecular and cellular mechanisms. Arch Toxicol 82:493-512. https://doi.org/10.1007/s00204-008-0313-y

Bianchi J, Espindola ELG, Marin-morales MA (2011) Genotoxicity and mutagenicity of water samples from the Monjolinho River (Brazil) after receiving untreated effluents. Ecotoxicol Environ Saf 74:826-833. https://doi.org/10.1016/j.ecoenv.2010. 11.006

Bolognesi C, Hayashi M (2011) Micronucleus assay in aquatic animals. Mutagenesis 26:205-213. https://doi.org/10.1093/mutage/ geq073

Carrasco KR, Tilbury KL, Mayers MS (1990) Assessment of the piscine micronuclei test as an in situ biological indicator of chemical contaminations effects. J Fish Aquat Sci 47:2123-2136. https://doi.org/10.1139/f90-237

Cavas T, Ergene-Gozukara S (2005a) Micronucleus test in fish cells: a bioassay for in situ monitoring of genotoxic pollution in the marine environment. Environ Mol Mutagen 46:64-70. https://doi.org/10.1002/em.20130

Cavas T, Ergene-Gozukara S (2005b) Induction of micronuclei and nuclear abnormalities in Oreochromis niloticus following exposure to petroleum refinery and chromium processing plant effluents. Aquat Toxicol 74:264-271. https://doi.org/10.1016/ j.aquatox.2005.06.001

Chakraborty R, Mukherjee A, Mukherjee A (2009) Evaluation of genotoxicity of coal fly ash in Allium cepa root cells by combining comet assay with the Allium test. Environ Monit Assess 153:151-157. https://doi.org/10.1007/s10661-008-0361-z

Chellappa NT, Costa MAS (2003) Dominant and co-existing species of cyanobacteria from a eutrophicated reservoir of Rio Grande do Norte State, Brazil. Acta Oecol 24:3-10. https://doi.org/10.1016/S1146-609X(03)00005-5

Chen JZ, Ye JY, Zhang HY, Jiang XJ, Zhang YX, Liu ZL (2011) Freshwater toxic cyanobacteria induced DNA damage in apple (Malus pumila), rape (Brassica napus) and rice (Oryza sativa). J Hazard Mater 190:240-244. https://doi.org/10.1016/j. jhazmat.2011.03.030

CONAMA (Conselho Nacional do Meio Ambiente), 2005. Resolução no. 357. Ministério do Meio Ambiente, MMA, Brasília, Distrito Federal. http://www.mma.gov.br/. Accessed 16 June 2015

Da Silva Souza T, Fontanetti CS (2006) Micronucleus test and observation of nuclear alterations in erythrocytes of Nile tilapia exposed to waters affected by refinery effluent. Mutat Res 605:87-93. https://doi.org/10.1016/j.mrgentox.2006.02.010

Da Silva PRR, Pires OR, Grisolia CK (2011) Genotoxicity in Oreochromis niloticus (Cichlidae) induced by Microcystis spp. bloom extract containing microcystins. Toxicon 58:259-264. https://doi.org/10.1016/j.toxicon.2011.06.005

Di Giorgio C, Malleret L, Gueydon-Morin C, Rigaud S, De Méo M (2011) Comparison of two extraction procedures for the assessment of sediment genotoxicity: implication of polar organic compounds. Mutat Res 725:1-12. https://doi.org/10.1016/ j.mrgentox.2011.05.012

Duarte ID, Dias DC, David JAO, Matsumoto JS (2012) A qualidade da água da Lagoa Jacuném (Espírito Santo, Brasil) em relação a aspectos genotóxicos e mutagênicos, mensurados respectivamente pelo ensaio do cometa e teste do micronúcleo em peixes da espécie Oreochromis niloticus. Rev Bras Biociências 10:211-219. http://www.ufrgs.br/seerbio/ojs/index.php/rbb/article/ view/2064

Erbe MCL, Ramsdorf WA, Vicari T, Cestari MM (2011) Toxicity evaluation of water samples collected near a hospital waste landfill through bioassays of genotoxicity piscine micronucleus test and comet assay in fish Astyanax and ecotoxicity Vibrio fischeri and Daphnia magna. Ecotoxicology 20:320-328. https://doi.org/10.1007/s10646-010-0581-1

Farmer PB, Singh R (2008) Use of DNA adducts to identify human health risk from exposure to hazardous environmental pollutants: the increasing role of mass spectrometry in assessing biologically effective doses of genotoxic carcinogens. Mutat Res 659:68-76. https://doi.org/10.1016/j.mrrev.2008.03.006

Fryzova R, Pohanka M, Martinkova P, Cihlarova H, Brtnicky M, Hladky J, Kynicky J (2018) Oxidative Stress and Heavy Metals in Plants. Rev Environ Contam Toxicol 245:129-156. https://doi.org/10.1007/398_2017_7

Gómez-mendikute A, Cajaraville MP (2003) Comparative effects of cadmium, copper, paraquat and benzo[a]pyrene o the actin cytoskeleton and production of reactive oxygen species (ROS) in mussel haemocytes. Toxicol In Vitro 17:539-546. https:// doi.org/10.1016/S0887-2333(03)00093-6

Grzesiuk M, Mielecki D, Pilżys T, Garbicz D, Marcinkowski M, Grzesiuk E (2018) How cyclophosphamide at environmentally relevant concentration influences Daphnia magna life history and its proteome. PLoS One 13:e0195366. https://doi.org/10. 1371/journal.pone.0195366

Hoshina MM, de Angelis DF, Marin-Morales MA (2008) Induction of micronucleus and nuclear alterations in fish (Oreochromis niloticus) by a petroleum refinery effluent. Mutat Res 656:44-48. https://doi.org/10.1016/j.mrgentox.2008.07.004 
Humpage AR, Fenech M, Thomas P, Falconer IR (2000) Micronucleus induction and chromosome loss in transformed human white cells indicate clastogenic and aneugenic action of the cyanobacterial toxin, cylindrospermopsin. Mutat Res 472:155-161. https://doi.org/10.1016/S1383-5718(00)00144-3

Jha AN (2004) Genotoxicological studies in aquatic organisms: an overview. Mutat Res 552:1-17. https://doi.org/10.1016/j. mrfmmm.2004.06.034

Kern DI, Schwaickhardt RO, Lutterbeck CA, Kist LT, Alcayaga EAL, Machado EL (2015) Ecotoxicological and genotoxic assessment of hospital laundry wastewaters. Arch Environ Contam Toxicol 68:64-73. https://doi.org/10.1007/s00244-0140072-0

Klobucar GI, Malev O, Šrut M, Štambuk A, Lorenzon S, Cvetković Ž, Ferrero EA, Maguire I (2012) Genotoxicity monitoring of freshwater environments using caged crayfish (Astacus leptodactylus). Chemosphere 87:62-67. https://doi.org/10.1016/j. chemosphere.2011.11.060

Leme DM, Marin-Morales MA (2009) Allium cepa test in environmental monitoring: a review on its application. Mutat Res 682:71-81. https://doi.org/10.1016/j.mrrev.2009.06.002

Leung KP, Chen D, Chan KM (2014) Understanding copper sensitivity in zebrafish (Danio rerio) through the intracellular localization of copper transporters in a hepatocyte cell-line ZFL and the tissue expression profiles of copper transporters. Metallomics 6:1057-1067. https://doi.org/10.1039/c3mt00366c

Lima PD, Leite DS, Vasconcellos MC, Cavalcanti BC, Santos RA, Costa-Lotufo LV, Pessoa C, Moraes MO, Burbano RR (2007) Genotoxic effects of aluminum chloride in cultured human lymphocytes treated in different phases of cell cycle. Food Chem Toxicol 45:1154-1159. https://doi.org/10.1016/j.fct.2006.12.022

Lürling M, van Oosterhout F, Faassen E (2017) Eutrophication and warming boost cyanobacterial biomass and microcystins. Toxins (Basel) 9(2):64. https://doi.org/10.3390/toxins9020064

Mackereth FJH, Heron J, Talling JF (1978) Water analysis: some revised methods for limnologists. Freshwater Biological Association, London

Mai H, Morin B, Pardon P, Gonzalez P, Budzinski H, Cachot J (2013) Environmental concentrations of irgarol, diuron and S-metolachlor induce deleterious effects on gametes and embryos of the Pacific oyster, Crassostrea gigas. Mar Environ Res 89:1-8. https://doi.org/10.1016/j.marenvres.2013.04.003

Manzano BC, Roberto MM, Hoshina MM, Menegário AA, Marin-Morales MA (2015) Evaluation of the genotoxicity of waters impacted by domestic and industrial effluents of a highly industrialized region of São Paulo State, Brazil, by the comet assay in HTC cells. Environ Sci Pollut Res 22:1399-1407. https://doi.org/10.1007/s11356-014-3476-5

Marcon AE, Ferreira DMF, Moura MFV, Campos TFC, Amaral VS, Agnez-Lima LF, Medeiros SRB (2010) Genotoxic analysis in aquatic environment under influence of cyanobacteria, metal and radioactivity. Chemosphere 81:773-780. https://doi.org/ 10.1016/j.chemosphere.2010.07.006

Matsumoto ST, Mantovani MS, Malaguttii MIA, Dias AL, Fonseca IC, Marin-Morales MA (2006) Genotoxicity and mutagenicity of water contaminated with tannery effluents and comet assay using the fish Oreochromis niloticus and chromosome alterations in onion root-tips. Genet Molecul Biol 29:148-158. https://doi.org/10.1590/S1415-47572006000100028

Oliva M, José Vicente J, Gravato C, Guilhermino L, Dolores Galindo-Riaño M (2012) Oxidative stress biomarkers in Senegal sole, Solea senegalensis, to assess the impact of heavy metal pollution in a Huelva estuary (SWSpain): seasonal and spatial variation. Ecotoxicol Environ Saf 75:151-162. https://doi.org/10.1016/j.ecoenv.2011.08.017

Peng C, Muthusamy S, Xia Q, Lal V, Denison MS, Ng JC (2015) Micronucleus formation by single and mixed heavy metals/loids and PAH compounds in HepG2 cells. Mutagenesis 30:593-602. https://doi.org/10.1093/mutage/gev021

Pereira S, Cavalie I, Camilleri V, Gilbin R, Adam-Guillermin C (2013) Comparative genotoxicity of aluminium and cadmium in embryonic zebrafish cells. Mutat Res 750:19-26. https://doi.org/10.1016/j.mrgentox.2012.07.007

Planap (2014) Plano de Ação para o Desenvolvimento Integrado da Bacia do Parnaíba. Síntese executiva: Território Vale do Rio Guaribas/Companhia de Desenvolvimento dos Vales do São Francisco e do Parnaíba - CODEVASF. - Brasília, DF: TDA Desenhos \& Arte Ltda. http://docplayer.com.br/247671-Plano-de-acao-para-o-desenvolvimento-integrado-da-bacia-do-usoda-terra-e-uso-do-cerrado.html

Rice EW, Baird RB, Eaton AD, Clesceri LS (2012) Standard methods for the examination of water and wastewater. American Public Health Association, American Water Works Association. Water Environ Fed 22. https://store.awwa.org/store/ productdetail.aspx?productid $=28493774$

Sieroslawska A (2013) Assessment of the mutagenic potential of cyanobacterial extracts and pure cyanotoxins. Toxicon 74:76-82. https://doi.org/10.1016/j.toxicon.2013.07.029

Ternjej I, Mihaljevi Z, Stankovi I, Kerovec M, Sipos L, Zeljezi D, Kopjar N (2010) Estimation of DNA integrity in blood cells of eastern mosquito fish (Gambusia holbrooki) inhabiting an aluminium-polluted water environment: an alkaline comet assay study. Arch Environ Contam Toxicol 59:182-193. https://doi.org/10.1007/s00244-010-9469-6

Tsangaris C, Vergolyas M, Fountoulaki E, Goncharuk VV (2011) Genotoxicity and oxidative stress biomarkers in Carassius gibelio as endpoints for toxicity testing of Ukrainian polluted river waters. Ecotoxicol Environ Saf 74:2240-2244. https://doi. org/10.1016/j.ecoenv.2011.08.010

Veloso RL, Deus MSM, Peron AP, Gonçalves NMN (2014) Plantas aquáticas: conhecimento de alunos do ensino médio da rede Pública de ensino sobre sua proliferação no rio Guaribas, Picos-PI. Ambiência 10:363-378. https://revistas.unicentro.br/ index.php/ambiencia/article/view/2451

Yu J, Dong HW, Shi LT, Jiang HL, Yu JW, Zhao QW, Cai SV, Han D, Tang XY, Liu JL (2013) Re-Examination of the genotoxic activity of water taken from the Songhua river in P. R. China. Arch Environ Contam Toxicol 65:78-88. https://doi.org/10. 1007/s00244-013-9876-6

Zegura B, Straser A, Filipi M (2011) Genotoxicity and potential carcinogenicity of cyanobacterial toxins-a review. Mutat Res 727:16-41. https://doi.org/10.1016/j.mrrev.2011.01.002 
Zhu Y, Wang J, Bai Y, Zhang R (2004) Cadmium, chromium, and copper induce polychromatocyte micronuclei in carp (Cyprinus carpio L.). Bull Environ Contam Toxicol 72:78-86. https://doi.org/10.1007/s00128-003-0243-6

Zitoun R, Clearwater SJ, Hassler C, Thompson KJ, Albert A, Sander SG (2019) Copper toxicity to blue mussel embryos (Mytilus galloprovincialis): The effect of natural dissolved organic matter on copper toxicity in estuarine waters. Sci Total Environ 653:300-314. https://doi.org/10.1016/j.scitotenv.2018.10.263

\section{Publisher's Note}

Springer Nature remains neutral with regard to jurisdictional claims in published maps and institutional affiliations. 